\section{Incidence of high blood pressure in a group of tannery workers in Brazil}

\author{
Incidência de hipertensão arterial sistêmica \\ entre trabalhadores de um curtume no Brasil
}

\author{
1 Departamento de Saúde \\ Pública, Faculdade de \\ Medicina de Botucatu, \\ Universidade Estadual \\ Paulista, Botucatu, Brasil. \\ Correspondence \\ R. Cordeiro \\ Departamento de Saúde \\ Pública, Faculdade \\ de Medicina de Botucatu, \\ Universidade \\ Estadual Paulista. \\ C. P. 543, Botucatu, SP \\ 18618-970, Brasil \\ cordeiro@fmb.unesp.br
}

\begin{abstract}
The aim of this study was to measure the incidence of high blood pressure (HBP) in a medium-size tannery in Botucatu, São Paulo State, southeast Brazil. A previous study at this tannery showed a high prevalence of arterial hypertension. A positive correlation was found between cumulated work time and arterial pressure. We followed a cohort of workers for seven years. At the end of this period, HBP incidence rate was calculated as 0.0964.year-1. This was considered high compared to other occupational groups.
\end{abstract}

Hypertension; Incidence; Tanning; Occupational
Ricardo Cordeiro 1

Eduardo Rommel Olivência Peñaloza 1 Maria Rita Camargo Donalisio 1

\section{Introduction}

Leather production is one of the world's oldest trades, consisting of a chemical process that turns animal hides into non-perishable material. During this process, after the removal of the epidermis and subcutaneous tissue, the dermal collagen fibers are stabilized by means of chemical treatment known generically as tanning.

Cordeiro et al. 1, in a cross-sectional study in 1993, reported the prevalence of systemic arterial hypertension or high blood pressure (HBP) among workers in a medium-sized tannery in the city of Botucatu, São Paulo, Brazil, calling attention to the high HBP prevalence as compared to other occupational groups in Brazil. More than half of the workers presented HBP. Subsequently, Cordeiro \& Lima Filho 2 found an association between cumulated work time at the tannery and diastolic arterial pressure in these workers. These two findings raised the hypothesis that the workers were exposed to some specific occupational risk (or set of risks), accounting for the increased arterial pressure in the group. The objective of the current study was to measure HBP incidence among workers in the same tannery in order to better characterize the previous finding. 


\section{Method}

Beginning with the baseline cross-sectional study conducted in 1993 1, a cohort of all the workers on the tannery production line was formed and followed up for seven consecutive years. Individuals were submitted to annual anthropometric measurement, measurement of arterial pressure, clinical history, and clinical examination. Measurements and examinations were always conducted in the month of July.

Anthropometric examination consisted of weight, height, and right arm circumference. Workers were weighed after bladder voiding and without wearing sweaters or coats. Height was measured with the workers barefoot, standing completely erect, and with their heels together.

At each annual examination, arterial pressure was measured three times in the morning, with a minimum interval of 15 minutes between each measurement, in a quiet waiting room, before the clinical history and examination, and after a minimum of thirty minutes of relative rest. The measurements were all taken on the right arm with the worker in the sitting position. The same mercury column sphygmomanometer was used, properly calibrated, with a $26 \times 12 \mathrm{~cm}$ cuff, and a stethoscope. Workers were oriented to empty their bladders before the measurement, as well as to refrain from smoking or drinking coffee or any other stimulant at least two hours prior to the first measurement and until after the third. Arterial pressure was measured by a technician who had received specific training for this purpose with audiovisual material prepared by the Nucleus for Educational Technology in Health (NUTES) at the Federal University in Rio de Janeiro (UFRJ). The recordings were made in millimeters, rounded to the nearest figure on the sphygmomanometer scale, which was graded to every two millimeters. Of the three measurements taken on each worker, the lowest diastolic pressure was always used, together with its respective systolic pressure. When the two lowest diastolic measurements coincided, this measurement was used, together with the lowest corresponding systolic pressure.

Diagnosis of HBP used the criteria recommended by the Sixth Report of the Joint National Committee on the Detection, Evaluation, and Treatment of High Blood Pressure 3 for individuals of both sexes 18 years of age and older. Thus, workers were diagnosed as hypertensive when they presented diastolic arterial pressure equal to or greater than $90 \mathrm{mmHg}$ and/or systolic arterial pressure equal to or greater than $140 \mathrm{mmHg}$, in addition to normotensive work- ers in regular use of antihypertensive medication. With the resulting data, we calculated the HBP incidence rate 4 in the study population.

\section{Results}

The follow-up began in July 1993, when all 57 workers on the tannery production line were evaluated. They worked a fixed day shift with an eight-hour workday and five-day workweek. Mean age and standard deviation in years were 48 and 11.4, respectively.

On this occasion it was determined that the mean cumulated work time in the cohort was 16 years. Mean monthly per capita income in over half the group was less than one minimum wage (approximately U\$80). About one-third of the group smoked in 1993, one-third reported never having smoked, and the remaining third consisted of former smokers. Forty-two per cent reported never or only occasionally drinking alcoholic beverages. The rest (58\%) consisted of drinkers or former drinkers. Smoking and alcoholism were associated with each other in the group. Only $58 \%$ of the workers showed body mass index (BMI) within normal limits, and overweight was the most frequent alteration. These results are provided in greater detail in Cordeiro et al. ${ }^{1}$ With the exception of cumulated work time, these variables presented only minor fluctuations in their distribution during the follow-up period.

The cohort was followed until July 2000, when 24 workers were at the same job positions and had similar work schedules as 1993 , with a mean age of 46 years (SD 10.0).

Table 1 shows the number of workers, mean age, and HBP prevalence for each annual examination.

In all, 88 workers were followed, all males, entering and leaving the study at different times as they were hired and laid off over the course of the study period. This cohort generated 286 years of follow-up (mean follow-up time: three years and three months), with a total of 124.5 HBP-free man-years. Twelve workers were identified who become hypertensive during follow-up, resulting in an HBP incidence rate of 0.0964. year-1 $^{-1}$ over the course of follow-up.

\section{Discussion}

There are few studies published thus far analyzing the distribution of systemic arterial hypertension among groups of Brazilian workers $1,2,5,6,7,8,9,10,11,12,13,14,15,16,17,18,19,20$. The vast ma- 
jority consists of cross-sectional studies that report distribution of arterial pressure and HBP prevalence in circumscribed occupational groups.

The tannery in this study underwent a technical restructuring process, pressured by the need to cut production costs to gain competitiveness in the Brazilian domestic leather market, increasingly disputed by other countries from Mercosur (the Southern Cone Common Market) in recent years. This process resulted in investments in new equipment, combined with more workers being laid off than hired, thus leading to a major downsizing over time, as shown in Table 1.

There is a surprisingly high HBP prevalence in the tannery workers at the beginning of the follow-up. As shown in Table 1, more than half were hypertensive in 1993. Over the course of seven years of follow-up, this prevalence showed a downward trend. All the workers diagnosed with HBP in the annual examinations were referred for outpatient treatment. According to the criteria adopted, the hypertensive workers whose blood pressure was controlled with medication continued to be diagnosed as hypertensive. Thus, the decrease in HBP prevalence was due to the entry of new normotensive workers into the cohort.

The high HBP incidence in the study group calls our attention. As reported, HBP incidence among the workers studied was 0.0964.year-1, or the equivalent of some one new case of HBP for every ten workers working one year in the tannery. There are no previous references to estimated HBP incidence rates in Brazil. This made it impossible to compare our estimate with that of other Brazilian occupational groups. The international literature refers to much lower rates, for example Koskela 21, who reports incidences rates of 0.0047 to 0.0099 .year-1 among Finnish metalworkers. However, the comparison of distribution of systemic arterial pressure among occupational groups in Brazil with occupational groups from other countries is of limited interest, since the ethnic, cultural, social, and labor differences extensively hinder the comparison of results. Nevertheless, the incidence presented here is surprising: despite
Table 1

Number of workers examined, mean age, and HBP prevalence in a cohort of tannery workers. Botucatu, São Paulo State, Brazil, 1993-2000.

\begin{tabular}{lcccc}
\hline $\begin{array}{l}\text { Date of } \\
\text { examination }\end{array}$ & $\begin{array}{c}\text { Number of } \\
\text { workers }\end{array}$ & $\begin{array}{c}\text { Mean age } \\
\text { (years) }\end{array}$ & $\begin{array}{c}\text { Standard } \\
\text { deviation }\end{array}$ & $\begin{array}{c}\text { HBP prevalence } \\
\text { (\%) }\end{array}$ \\
\hline July 1993 & 57 & 48 & 11.4 & 56.1 \\
July 1994 & 54 & 45 & 10.9 & 46.3 \\
July 1995 & 55 & 45 & 10.5 & 43.6 \\
July 1996 & 46 & 44 & 11.0 & 42.6 \\
July 1997 & 40 & 45 & 12.1 & 52.5 \\
July 1998 & 28 & 45 & 11.8 & 32.1 \\
July 1999 & 32 & 46 & 10.5 & 40.6 \\
July 2000 & 24 & 46 & 10.0 & 29.2 \\
\hline
\end{tabular}

the differences among the groups studied, it was 6 to 21 times greater than the incidence rate found in Finnish metalworkers.

The specialized literature does not establish an association between tannery work and HBP, although it is common for tanneries to present major exposure to industrial noise and heat, both of which are factors known to be associated with hypertension. In the tannery studied here, the sound pressure and heat overload are in fact high. However, these exposures alone do not appear to explain the high HBP incidence we found. These factors also exist (and even to a greater degree) in other local occupational groups, for example, metalworkers and woodworkers in two large factories in Botucatu, but the workers there do not have significantly higher arterial pressure than the average population in the city, despite the possibility of the healthy worker effect confounding this relationship.

Finally, the results of this study point to two pressing needs. First, rigorous clinical followup of the tannery workers is needed, whether or not they are hypertensive. Second, the study calls for further investigation, aimed at isolating the possible causal factors involved in the increased blood pressure levels in the study population in order to intervene in the work process to make it less hazardous. 
O objetivo deste estudo foi medir a incidência de hipertensão arterial sistêmica em um curtume de médio porte em Botucatu, São Paulo, Sudeste do Brasil, onde havia sido observada, em estudo prévio, uma correlação positiva entre tempo de trabalho e niveis pressóricos, bem como uma alta prevalência de hipertensão. Para tanto, uma coorte de trabalhadores desse curtume foi acompanhada durante sete anos. Ao final do seguimento, estimou-se a taxa de incidência de hipertensão arterial como 0,0964.ano-1, valor considerado elevado se comparado com o encontrado em outros grupos profissionais.

Hipertensão; Incidência; Curtume; Saúde Ocupacional

\section{References}

1. Cordeiro R, Lima Filho EC, Almeida IM. Pressão arterial entre trabalhadores de um curtume. Rev Saúde Pública 1998; 32:467-76.

2. Cordeiro R, Lima Filho EC. Association between diastolic blood pressure and cumulative work time. Cad Saúde Pública 1999; 15:63-70.

3. Joint National Committee on Detection, Evaluation, and Treatment of High Blood Pressure. The Sixth Report of the Joint National Committee on Detection, Evaluation, and Treatment of High Blood Pressure (JNC VI). Arch Intern Med 1997; 157:2413-45.

4. Santana VS, Cordeiro R. Detecção de agravos à saúde relacionados com o trabalho em estudos epidemiológicos. In: Mendes R, organizador. Patologia do trabalho. São Paulo: Atheneu; 2002. p. 199-229.

5. Araújo JWG. Hipertensão arterial em grupos sócio-econômicos de Volta Redonda-RJ [Dissertação de Mestrado]. Rio de Janeiro: Escola Nacional de Saúde Pública, Fundação Oswaldo Cruz; 1984.

6. Carvalho JJM, Silva NAS, Oliveira JM, Arguelles E, Silva JAF. Pressão arterial e grupos sociais. Estudo epidemiológico. Arq Bras Cardiol 1983; 40:115-20.

7. Chor D. Hipertensão arterial entre funcionários de banco estatal no Rio de Janeiro. Hábito de vida e tratamento. Arq Bras Cardiol 1998; 71:653-60.

8. Cordeiro R. Pressão arterial diastólica entre motoristas e cobradores de Campinas, usuários de um serviço de saúde ocupacional [Dissertação de Mestrado]. Campinas: Faculdade de Ciências Médicas, Universidade Estadual de Campinas; 1991.

9. Cordeiro R, Fischer FM, Lima Filho EC, Moreira Filho DC. Associação entre pressão arterial diastólica e tempo acumulado de trabalho em motoristas e cobradores. Rev Saúde Pública 1993; 27: 363-72.

10. Corrêa Filho HR, Costa LS, Hoehne EL. Perda auditiva induzida por ruído e hipertensão em condutores de ônibus. Rev Saúde Pública 2002; 36: 693-701.

11. Klein CH. Hipertensão arterial entre extratos geoeconômicos do Rio Grande do Sul [Dissertação

\section{Contributors}

R. Cordeiro, E. R. O. Peñaloza, and M. R. C. Donalísio participated in the overall study concept and design, data collection, data analysis, and drafting of the paper. de Mestradol. Rio de Janeiro: Escola Nacional de Saúde Pública; Fundação Oswaldo Cruz; 1981.

12. Klein $\mathrm{CH}$, Araújo JWG. Fumo, bebida alcoólica migração, instrução, ocupação, agregação familiar e pressão arterial em Volta Redonda, Rio de Janeiro. Cad Saúde Pública 1985; 1:160-76.

13. Klein CH, Coutinho ESF, Camacho LAB. Variação da pressão arterial em trabalhadores de uma siderúrgica. Cad Saúde Pública 1986; 2:212-26.

14. Kloetzel K, Andrade AE, Falleiros J, Pacheco JC Relationship between hypertension and prolonged exposure to heat. J Occup Health 1973; 15:878-85.

15. Lima CT, Carvalho FM, Quadros CA, Gonçalves HR, Silva Júnior JA, Peres MF, et al. Hipertensão arterial e alcoolismo em trabalhadores de uma refinaria de petróleo. Rev Panam de Salud Pública 1999; 6:185-91.

16. Melhado JC, Mosa ALP, Dine JM. Avaliação de níveis de pressão arterial em operários da construção civil. Rev Bras Saúde Ocup 1984; 45:68-73.

17. Ribeiro MD. Hypertension among female work ers in São Paulo, Brazil: predictors and joint effects. Hypertension 1983; 5:144-8.

18. Ribeiro MD, Ribeiro AB, Stabille Neto C, Ancão MS. Hypertension and economic activities in São Paulo, Brazil. Hypertension 1981; 3:233-7.

19. Rocha R, Porto M, Morelli MYG. Efeito de estresse ambiental sobre a pressão arterial de trabalhadores. Rev Saúde Pública 2002; 36:568-75.

20. Souza NSS, Carvalho FM, Fernandes RDCP. Hipertensão arterial entre trabalhadores de petróleo expostos a ruído. Cad Saúde Pública 2001, 17:1481-8.

21. Koskela RS. Cardiovascular diseases among foundry workers exposed to carbon monoxide. Scand J Work Environ Health 1994; 20:286-93.

Submitted on 26/Mar/2003

Final version resubmitted on $24 /$ Oct $/ 2003$ Approved on 11/Nov/2003 